\title{
Pengaruh Suplementasi Jintan Hitam (Nigella sativa) Giling terhadap Aspartate Aminotransferase (AST), Alanine Aminotransferase (ALT) dan Berat Organ Hati Broiler
}

\author{
The Effect of Black Cumin (Nigella sativa) Grinding Supplementation on Aspartate \\ Aminotransferase (AST), Alanine Aminotransferase (ALT) and Liver Weight on Broiler
}

\author{
S. Salam, D. Sunarti, dan Isroli \\ Fakultas Peternakan dan Pertanian Universitas Diponegoro \\ Jl. Prof H. Soedarto, SH Kampus Tembalang Semarang, 50275 \\ e-mail: syahfiisalam@gmail.com \\ (Diterima: 12 Agustus 2013; Disetujui: 18 Januari 2014)
}

\begin{abstract}
ABSTRAK
Penelitian ini untuk menentukan aspartate aminotransferase (AST), alanine aminotransferase (ALT) dan berat organ hati pada ayam broiler, setelah disuplementasi jintan hitam giling (Nigella sativa). Materi yang digunakan adalah DOC ayam broiler unsex strain CP 707 sebanyak 100 ekor, menggunakan rancangan acak lengkap (RAL) dengan 5 perlakuan dan 4 kali ulangan. Tiap ulangan terdiri atas 4 unit percobaan yaitu kontrol, antibiotik dan tanpa jintan hitam giling, dengan suplementasi $2 \% / \mathrm{kg}, 4 \% / \mathrm{kg}$ dan $6 \% / \mathrm{kg}$. Kerja enzim hati dan berat organ hati diukur setelah 30 hari. Penambahan jintan hitam giling pada ayam broiler tidak signifikan pengaruhnya pada enzim hati (AST dan ALT) dan relatif signifikan pada berat organ hati. Disimpulkan bahwa penambahan jintan hitam giling sebagai pakan tambahan tidak menunjukkan dampak negatif terhadap enzim hati seperti AST dan ALT, dan berat organ hati dengan penambahan jintan hitam giling sebagai pakan tambahan yang digunakan pada level $2-6 \% / \mathrm{kg}$ pada ayam broiler.
\end{abstract}

Kata kunci : Nigella sativa, AST, ALT, berat organ hati

\section{ABSTRACT}

This study was designed to determine the aspartate aminotransferase (AST), alanine aminotransferase (ALT) and liver weight of broiler after black cumin grinds (Nigella sativa). A total number of 100 unsexed one-day old broilers were used in this experiment. The experiment was designed in a completely randomized design with 5 different levels of black cumin grinds (BCG) (control, antibiotics and without BCG, 2\%/kg BCG, 4\%/kg BCG and 6\%/kg BCG) in diet. Liver's enzymes activity and liver weight were measured on broiler in 30 day of age. Result showed, the addition of BCG in broiler's diet had no significant effects on liver's enzymes (AST and ALT) and relative weights of liver. It was concluded that the addition of black cumin grinds (Nigella sativa) as a feed additive did not show the negative impact on liver's enzymes and liver weight, and the including 2-6\%/kg of black cumin (Nigella sativa) could be used as feed additive in broiler's diet.

Keywords: Nigella sativa, AST, ALT, liver weight

\section{PENDAHULUAN}

Imbuhan pakan (feed additives) adalah suatu bahan yang dicampurkan di dalam pakan yang dapat mempengaruhi kesehatan dan produktifitas ternak, meskipun bahan tersebut bukan untuk mencukupi kebutuhan zat gizi
(Agustina, 2006). Imbuhan pakan yang sudah umum digunakan dalam industri perunggasan adalah antibiotik karena dipercaya dapat menekan pertumbuhan bakteri-bakteri patogen dalam saluran pencernaan (Sims et al., 2004; Engberg et al., 2000). Hasil penelitian lain menunjukkan penggunaan antibiotik secara 
berlebihan akan menimbulkan gangguan keseimbangan atau ketidakstabilan mikroorganisme dalam saluran pencernaan serta resistensi mikroorganisme terhadap antibiotik (An den bogaard dan Stobberingh, 2000). Sehingga perlu alternatif feed additive alami pengganti antibiotik yang dapat meningkatkan kekebalan tubuh ternak yang aman bagi kesehatan manusia. Kandungan biokimia darah yang dapat digunakan sebagai dasar tingkat keamanan ternak akibat pemberian feed additive alami antara lain enzim aspartate aminotransferase (SGOT) dan alanine aminotransferase (SGPT). Menurut Martazani dan Murwani (2005) kandungan enzim SGPT dan SGOT dapat digunakan sebagai indikator untuk mengetahui adanya pengaruh negatif berupa kerusakan sel-sel hati akibat pemberian ekstrak mengkudu sebagai feed additive. Enzim SGPT dilepas ke dalam aliran darah akibat dari kerusakan hati, oleh karenanya SGPT digunakan sebagai suatu indikator yang cukup spesifik dari keadaan hati maupun kesehatan ternak (Franson et al., 1985; Murwani et al., 2011; Suarsana et al., 2006).

Salah satu alternatif pengganti antibiotik sintetik yang dapat meningkatkan ketahanan tubuh ternak adalah penggunaan tanaman herbal. Tanaman herbal yang dapat meningkatkan daya tahan tubuh pada ayam broiler adalah jintan hitam karena memiliki kandungan berupa thymoquinone yang berfungsi sebagai antioksidan, antiinfeksi, antitumor dan antiinflamasi (Ragheb et al., 2009). Sebuah penelitian menunjukkan bahwa dengan pemberian jintan hitam yang mengandung thymoquinone dapat menyebabkan peningkatan secara signifikan terhadap jumlah leukosit, $\mathrm{Hb}$ dan alanine aminotransferase (AlHomidan et al., 2002; Hermes et al., 2010). Kandungan serbuk jintan hitam berupa zat aktif (thymoquinone, dithymoquinone, thymol, dan carvacrol) dapat meningkatkan kecernaan dan absorbsi zat makanan dengan cara menstimulasi enzim-enzim pencernaan (Nasir, 2009). Hasil penelitian lainnya yang menunjukkan tidak adanya pengaruh racun dalam jintan hitam dinyatakan oleh El-Daly (1996) yaitu pemberian jintan hitam dapat digunakan sebagai antitoksik pada perlakuan mencit dengan level pemberian tepung jintan dengan taraf normal. Oleh karena itu diharapkan dari hasil penelitian ini menjadi dasar penggunaan jintan hitam sebagai feed additive yang aman digunakan untuk ayam broiler.

\section{METODE}

Materi yang digunakan dalam penelitian ini adalah day old chick (DOC) ayam broiler unsex strain CP 707 sebanyak 100 ekor. Rancangan penelitian yang digunakan adalah Rancangan Acak Lengkap (RAL) dengan 5 perlakuan dan 4 ulangan, dan tiap ulangan terdiri atas 4 unit percobaan. Metode penyusunan ransum percobaan yang digunakan adalah metode "trial and error"dan sampel bahan pakan dianalisis proksimat di Laboratorium Ilmu Nutrisi Pakan Ternak, Fakultas Peternakan dan Pertanian, Universitas Diponegoro Semarang. Susunan ransum dan kandungan nutrisinya pada penelitian ini terdapat dalam Tabel 1.

\section{Aktivitas Enzim SGOP dan SGPT}

Akhir penelitian pada ayam umur 30 hari ayam dari tiap unit percobaan diambil darahnya masing-masing sebanyak $2 \mathrm{ml}$ menggunakan spuit $3 \mathrm{ml}$ melalui pembuluh darah yang ada pada sayap bagian dalam (vena brachialis). Darah kemudian dimasukkan ke dalam tabung vacutainer yang telah berisi EDTA sebagai koagulan dan digoyanggoyangkan secara perlahan sampai EDTA larut dalam darah. Selanjutnya tabung yang telah berisi darah dimasukkan kedalam termos berisi es dan dibawa ke laboratorium terkait untuk dianalisis kadar SGPT dan SGOT. Kadar SGPT dan SGOT ditentukan dengan metode spektrofotometri menggunakan reagen KIT Humazym-UV test (Cat- No. 10001 dan 10002). Prosedurnya adalah sebagai berikut : pembuatan monoreagen, yaitu dengan 4 cara bagian reagen 1 dicampur dengan bagian reagen 2. Pada microplate, sebanyak $100 \mu \mathrm{l}$ sampel serum dicampur dengan $1000 \mu \mathrm{l}$ monoreagen pada suhu $37^{\circ} \mathrm{C}$ kemudian diinkubasikan selama 1 menit. Aktivitas SGOT atau SGPT dibaca dengan alat spektrofotometer pada panjang gelombang ( $\lambda$ ) $340 \mathrm{~nm}$. 
Vol. $16(1)$

Tabel 1. Susunan ransum penelitian

\begin{tabular}{ccc}
\hline Komponen & $\begin{array}{c}\text { Starter } \\
\text { (usia } 1-3 \text { minggu) }\end{array}$ & $\begin{array}{c}\text { Grower } \\
\text { (usia } 4-5 \text { minggu) }\end{array}$ \\
\hline Jenis Bahan Pakan (\%) & 51 & 55 \\
Jagung & 15 & 17 \\
Bekatul & 20 & 13 \\
Bungkilkedelai & 11 & 11 \\
Tepungikan & 2 & 3 \\
Minyaksawit & 0,5 & 0,5 \\
Kapur & 0,5 & 0,5 \\
Top Mix & & \\
EM (kkal/kg) & 2.994 & 3.054 \\
PK (\%) & 22,91 & 20,01 \\
LemakKasar (\%) & 5,89 & 7,04 \\
SeratKasar $(\%)$ & 6,17 & 6,44 \\
Kalsium (Ca) $(\%)$ & 1,05 & 1,03 \\
Fosfor (P) (\%) & 2,23 & 2,45 \\
Metionin (\%) & 0,45 & 0,42 \\
Metionin + Sistin (\%) & 0,76 & 0,69 \\
Lisin & 1,34 & 1,16
\end{tabular}

Sumber: Laboratorium Ilmu Nutrisi Pakan Ternak Fakultas Peternakan dan Pertanian, Universitas Diponegoro (2013).

\section{Berat Organ Hati}

Bobot organ hati diperoleh dengan cara menimbang organ hati dari ayam broiler umur 30 hari setelah dilakukan pemotongan. Organ diambil dengan peralatan bedah patologi. Organ dipisahkan dengan hati-hati dari jaringan sekitar. Setelah organ tersebut dipisah kan kemudian dilakukan penimbangan dan dicatat hasilnya. Sampel organ tersebut kemudian diberi label. Nilai persentase berat relatif organ hati diperoleh dari pembagian berat organ hati dengan bobot hidup ayam dikalikan dengan $100 \%$.

\section{Analisis Data}

Data yang diperoleh dianalisis ragam dengan uji $\mathrm{F}$ dan apabila terdapat pengaruh perlakuan yang nyata, maka dilanjutkan dengan uji wilayah ganda Duncan's untuk mengetahui perbedaan antar perlakuan. Kriteria pengambilan keputusan pada taraf kepercayaan $95 \%$ atau $\alpha=0,05$.

\section{HASIL DAN PEMBAHASAN}

\section{Pengaruh Jintan Hitam Terhadap Serum Glutamat Piruvat Transaminase dan Serum Glutamat Oksaloasetat Transaminase.}

Rataan jumlah enzim serum glutamate piruvat transaminase dan serum glutamate oksaloasetat transaminase pada ayam broiler disajikan pada Tabel 2. Rataan jumlah enzim SGPT dan SGOT masing-masing sebesar $3,202 \pm 0,20 \mathrm{U} / \mathrm{L}$ dan $4,803 \pm 0,53 \mathrm{U} / \mathrm{L}$. Rataan total enzim SGPT dan SGPT pada hasil penelitian nilai menunjukkan angka standar normal, walaupun standar normal enzim SGPT dan SGOT pada ayam broiler masing belum diketahui secara pasti. Menurut Daneshyer et al. (2009) aktivitas enzim ALT pada ayam broiler berkisar antara 1,044-3,092 U/L. Keberadaan SGPT dalam kondisi normal dalam darah terjadi karena regenerasi sel hati yang terjadi secara normal. Aktivitas enzim 
Tabel 2. Rataan nilai Serum Glutamat Piruvat Transaminase (SGPT) dan Serum Glutamat Oksaloasetat Transaminase (SGOT) (Mean \pm Standard Error)

\begin{tabular}{cccc}
\hline Perlakuan & SGPT (U/L) & SGOT (U/L) & Hati (\%Berat Hidup) \\
\hline T0 & $3,64 \pm 0,73$ & $4,37 \pm 0,84$ & $2,89 \pm 0,29$ \\
T1 & $3,64 \pm 0,73$ & $5,82 \pm 2,06$ & $2,75 \pm 0,17$ \\
T2 & $2,91 \pm 0,00$ & $4,37 \pm 0,84$ & $2,68 \pm 0,31$ \\
T3 & $2,91 \pm 0,00$ & $5,09 \pm 1,39$ & $2,55 \pm 0,13$ \\
T4 & $2,91 \pm 0,00$ & $4,37 \pm 0,84$ & $2,67 \pm 0,12$ \\
\hline Rata-rata & $3,20 \pm 0,20^{\text {ns }}$ & $4,80 \pm 0,53^{\text {ns }}$ & $2,71 \pm 0,09^{\text {ns }}$ \\
\hline
\end{tabular}

SGPT dan SGOT dapat digunakan sebagai indikator kesehatan ternak seperti kerusakan sel-sel yang terdapat di dalam organ hati akibat perlakuan pemberian pakan atau feed additive. Menurut Martani dan Murwani (2005) kandungan enzim SGPT dan SGOT dapat digunakan sebagai indikator untuk mengetahui adanya pengaruh negatif berupa kerusakan sel-sel hati akibat pemberian ekstrak mengkudu. Berdasarkan hasil statistik, penggunaan jintan hitam sebagai imbuhan pakan dalam ransum tidak berpengaruh nyata $(\mathrm{P}>0,05)$ terhadap jumlah SGPT dan SGOT dalam darah ayam broiler maupun terhadap kontrol. Hal ini mungkin disebabkan karena level pemberian jintan hitam yang diberikan dalam jumlah rendah, sehingga asupan zat aktif yang dikonsumsi oleh ayam tidak dapat menurunkan aktivitas enzim secara signifikan. Penelitian ini mengindikasikan bahwa level pemberian jintan hitam 2-6\% dalam ransum tidak berdampak negatif terhadap kerusakan sel-sel jaringan yang dilihat dari nilai aktivitas enzim dengan nilai normal. Hasil penelitian yang sama juga dinyatakan oleh Menurut AlHomidan et al. (2002) bahwa biji jintan hitam yang diberikan pada ransum ayam umur 7 minggu $20 \mathrm{~g} / \mathrm{kg}$ dan $100 \mathrm{~g} / \mathrm{kg}$ ransum tidak mempengaruhi perubahan aktivitas dalam serum aspartate transaminase (AST) dan alanine transaminase (ALT).

\section{Berat Organ Hati}

Rataan persentase berat organ hati pada

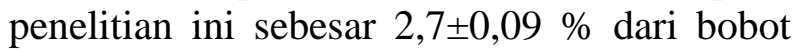
hidup (Tabel 2). Berat relatif hati pada penelitan ini menunjukan berat normal. Menurut Ologhobo et al. (1993) berat hati ayam broiler umur 4 minggu sebesar 2,64-
4,40\%. Berdasarkan hasil statistik menunjukkan tidak ada pengaruh nyata $(\mathrm{P}>0,05)$ pemberian jintan hitam terhadap berar relatif hati. Hal yang sama juga dinyatakan oleh ElDaly (1996) bahwa tidak ada pengaruh toksik pada jintan hitam dan bahkan jintan hitam dapat digunakan sebagai antitoksik pada perlakuan mencit dengan level pemberian tepung jintan dengan taraf normal. Menurut Al-Baitawi dan El-Ghousein (2008) menyatakan bahwa pemberian level tepung jintan hitam tidak dapat meningkatkan berat hati dan gizzard. Hal yang sama juga dinyatakan oleh Shewita dan Taha (2011) bahwa tidak ada pengaruh suplementasi, tidak ada pengaruh persentase berat hati pada pemberian level jintan 2 dan $3 \% / \mathrm{kg}$ ransum tetapi terjadi peningkatan hati pada level $1 \% / \mathrm{kg}$ ransum. Hasil penelitian ini membuktikan bahwa semua perlakuan dalam penelitian ini tidak mengandung zat toksik yang dapat merusak sel-sel di dalam hati. Berat hati akan meningkat disebabkan karena kerja sel hati tinggi untuk menyaring racun (toksik) dalam darah. Hal tersebut didukung oleh data parameter enzim ALT dan AST pada perlakuan jintan hitam maupun perlakuan lainnya (Tabel 2).

Aktivitas enzim SGPT dan SGOT merupakan dua enzim transaminase yang dihasilkan terutama oleh sel-sel. Aktivitas enzim SGPT yang dilepas ke dalam aliran darah merupakan akibat dari kerusakan hati, oleh karenanya SGPT digunakan sebagai suatu indikator terhadap kerusakan sel-sel hati. Gangguan kerusakan sel hati tidak selalu dapat diamati secara klinis karena jaringan hati memiliki kemampuan regenerasi jaringan yang tinggi (Subronto, 1987). 


\section{KESIMPULAN}

Hasil penelitian menunjukkan bahwa pemberian tepung jintan hitam (Nigella sativa) dalam pakan tidak menunjukkan dampak negatif terhadap enzim hati seperti AST dan ALT, serta berat organ hati yang normal sehingga jintan hitam aman digunakan sebagai feed additive alami pada level 2-6\% untuk ayam broiler.

\section{DAFTAR PUSTAKA}

Agustina, L. 2006. Penggunaan ramuan herbal sebagai feed additive untuk meningkatkan performans broiler. Lokakarya Nasional Inovasi Teknologi dalam Mendukung Usaha Ternak Unggas Berdaya Saing. Makasar. Hlm. 47-52.

Al-Baitawi, N and S. S. El-Ghousein. 2008. Effect of feeding different levels of Nigella sativa seeds (black cumin) on performance, blood constituents and carcass characteristics of broiler chicks. Int. J. Poult. Sci. 7(7): 715-721.

Al-Homidan, A., A. A. AL-Qarawi, S. A. AlWaily, and S. E. I. Adam. 2002. Response of broiler chicks to dietary Rhazyastricta and Nigella sativa. Poult. Sci. 43(2): 291-296.

An den Bogaard, A. E. and E. E. Stobberingh. 2000. Epidemiology of resistance to antibiotics. Int. J. Ant. Agents. 24: 327335.

Engberg, R. M., M. S. Hedemann, T. D. Leser and B. B. Jensen. 2000. Effect of zinc bacitracin and salinomycin on intestinal micro flora and performance of broilers. Poult. Sci. 79:1311-1319.

Daneshyar, M., H. Kermanshahi and A. Golian. 2009. Changes of biochemical parameters and enzyme activities in broiler chickens with cold-induced ascites. Poult. Sci. 88:106-110.

El-Daly, E. S. 1996. Protective effect of cysteineand vitamin e, crocus sativus and Nigella sativa extracts oncisplatin- induced toxicity in rats. J. Islamic Academy Sci. 9(4): 105-118.

Franson, J. C., H. C. Murray and C. Bunck. 1985. Enzyme activities in plasma, kidney, liver, and muscle of five avian species. J. Wild. Diseases. 21(1): 33-39.

Hermes, I. H., F. M. Attia, K. A. Ibrahim and S. S. El-Nesr. 2010. Physiological responses of broiler chickens to dietary different forms and levels of Nigella sativa L. during egyptian summer season. J.Agri. and Vet. Sci. 4(1): 17-33.

Martani, H. R dan R. Murwani. 2005. Aktivitas serum glutamat oksalo asetat transaminase dan serum glutamat piruvat transaminase broiler yang diberi ekstrak mengkudu (Morinda citrifolia) sebagai alternatif aditif klortetrasiklin. Prosiding Seminar Nasional. Fakultas Peternakan UGM, Yogyakarta.

Murwani, R., A. Indriani, I. Yuliana, K. Wihardani, M. A. Wahyuningrum, N. R. Tawakal, Mulyono and E. Kusumanti. 2011. Blood biochemical indices and productivity of broilers on diet supplemented with mannan oligosaccharide, baker yeast, orcombined baker yeast and noni leaves extracts. Int. J. Poult. Sci.10(12): 990-997.

Nasir, Z. 2009. Comparison of effects of Echinacea purpure a juices and Nigella sativa seeds on performance, some blood parameters, carcass and meat quality of broilers. University of Hohenheim. (Dissertation Agricultural of Sciences).

Ologhobo, A. D., D. F. Apata, A. Oyejide and O. Akinpelu. 1993. Toxicity of raw Limabeans (Phaseolus lunatus L.) and Limabean fractions for growing chickens. British Poultry Sci. 34(3): 505-532.

Regheb, A., A. Attia, W. S. Eldin, F. Elbarbry, S. Gazarin and A. Shoker. 2009. The protective effect of tymoquinone, an anti-oxidant and anti-inflammatory 
agent, againt renal injury: A Review. Saudi J Kidney Dis Transpl. 20(5): 741752.

Sims, M. D., K. A. Dawson, K. E. Newman, P. Spring and D. M. Hooge. 2004. Effects of dietary mannan oligosaccharide, bacitracin methylenedisalicylate, or both on the live performance and intestinal microbiology of turkeys. Poult.Sci. 83:1148-1154.

Suarsana, Y., N. Y. W. Susari, T. Wresdiyati dan A. Suprayogi. 2006. Penggunaan ekstrak tempe terhadap fungsi hati tikus dalam kondisi stres. J. Vet. 7(2): 54-61.

Subronto. 1984. Ilmu Penyakit Ternak. Gadjah Mada University Press, Yogyakarta. 